\title{
The Affect of The Asean China Free Trade Agreement (ACFTA) on The SME'S Performance
}

\author{
Wisnu Panggah Setiyono, Dewi Andriyani, Boy Isma Putra \\ Department of Management, Faculty of Economics and Busines, Universitas Muhammadiyah Sidoarjo, Indonesia
}

This research is aimed to analyze the influence of ASEAN-China Free Trade Agreement (ACFTA) on the financial performance of SME's in Sidoarjo. The financial performance of SME'S in this study was measured by the level of sales comparation between the period before and after ACFTA. This research applied mix method technique with squids mixed method strategy, especially sequential explanatory strategy. It is a strategy for the researchers to combine the data that was found from one method with the other method. The steps were begun with the researcher collecting the quantitative data by performing different test or Paired samples T-test then continued with collecting the qualitative data by doing library research. The results show that there are significant differences in financial performance; first, it is seen from the sales between before and after ACFTA, and second, it is proven that that the existence of ACFTA significantly affects the sales rate of SME's.

Keywords: Financial Performance, Sales, ACFTA

\section{INTRODUCTION}

In 2010, free trade did provide benefits, especially to consumers with many kinds of products at lower prices. On the other hand, this causes losses to companies with non-competitive products. Before the existence of free trade with China, Indonesia had been flooded with Chinese products. This will increase due to the application of free import duties or with a zero percent tariff, which is the same as the legalization of smuggling. Local (non-competitive) products are mainly subtitive products. So if two or more products are subtitively priced at lower prices, the

OPEN ACCESS ISSN 2528-4649 (online) ISSN 2338-4409 (print)

*Correspondence:

Received: 28 Agustus 2018 Accepted: 28 Agustus 2018 Published: 04 Maret 2019

Citation:

Setiyono WP, Andriyani D and Putra Bl (2019) The Affect of The Asean China Free Trade Agreement (ACFTA) on The SME'S Performance. Jurnal Bisnis, Manajemen dan

Perbankan . 5:1. doi: http://doi.org/10.21070JBMP.V item will be chosen by the consumer. As a result, many companies that are less competitive must go bankrupt or have to do contraction due to the aggregate expenditure of society on national industry products is smaller than national deposits (the amount of goods produced), then there is a reduction in labor which results in a large number of unemployed.

The traffic of goods and services with large capacity moves quickly from one country to another as if there is no limit. Countries that do not respond quickly will lose potential markets and will be left behind by other countries. This condition will certainly result in a pattern of inter-state trade relations (Sari Velinda Yola Yola (2017) ). The ACFTA begins with an inter-head of ASEAN and China meeting held at Bandar Sri Begawan, Brunei Darussalam on November 6, 2001, which was then ratified by the signing of a Framework Agreement. regarding Comprehensive Economic Cooperation between ASEAN Member Countries and the People's Republic of China in Phnom Penh, Cambodia on November 4, 2002. 
The agreement on the goods sector is a concrete form of the first economic cooperation between ASEAN and China with the signing of a Trade in Goods Agreement and Dispute Settlement agreement Mechanism Agreement on November 29, 2004 in Vietnam, Laos, "in Indonesia ACFTA (AseanChina Free Trade Agreement) through Presidential Decree No. 48 of 2004 dated June 15, 2004. That free trade agreement between ASEAN and China countries took effect January 1, 2010 "(Efnita, 2012 Efnita (2012) ).

The main problem with the ACFTA agreement in Indonesia is that it turns out that there are many stakeholders who request that the validity of this agreement be renegotiated by the government. Indonesian business people and economic experts predict that the national economic resilience will fall with the invasion of Chinese products to Indonesia. The role of the government is very important in implementing the ACFTA agreement to ensure the Fair Trade Competition, not the Unfair Trade Competition. With the presence of ACFTA, creative and innovative young entrepreneurs emerged and began to create their own jobs.

Sidoarjo has a lot of people's economic activities with the Small and Medium Enterprises (SMEs) and Large-sized Enterprises (LSEs). Data from the Sidoarjo Regency (Statistics Indonesia) shows that, "The total Micro, Small and Medium Enterprises (MSMEs) in Sidoarjo reached 206,934 business units. The details of the Medium Industry are 201,919, and Large Industry is 5,015, with the number of workers absorbed in the large Industry 103,899, and the Medium Industry 16,958 workers (Central Statistics Agency Statistik (2017)).

The distribution of the number of businesses / companies between sub-districts in Sidoarjo Regency can be seen in the table below.

Source: Central Statistics Agency of Sidoarjo

The innovation of Chinese products entering Indonesian market will certainly disrupt the domestic market especially for SMEs if their products cannot compensate in terms of price, quality, etc. What is worrying is that SME products will shift more and more into the point of purchasing power because the production is too expensive with almost the same quality as the products from China. Moreover, China sold its products with dumping penetration on alternative markets in the world including in Indonesia after the demand for their main markets such as Europe and the United States dropped sharply due to the global economic crisis as expressed in the Pikiran Rakyat Daily (8 October 2009 ). This aggressive condition causes domestic products not to become kings in their own country.

This phenomenon can cause changes in the production cycle and the performance of SMEs. To find out how much influence it has on SMEs, a performance measurement is needed. Performance measurement is a periodic determination of the operational effectiveness of an organization, part of an organization and employees based on a predetermined target, standard and criteria (Mulyadi Mulyadi (1997)).

(Helfert Erich A A (1996) ) reveals that it is important to realize that different measurement techniques will be suitable for different purposes, so before measurement is done it must clearly define the elements of the viewpoint taken, the purpose of the analysis, and potential comparison standards. In terms of point of view, it is also divided into three elements, namely management, owner and lender. In connection with the assessment of the performance of SMEs with the aim of observing changes in financial position as material for consideration of decisions for the benefit of SME management, one of the information that can be used for these measurements is the level of sales. Sales is an integrated effort to develop strategic plans that are directed at the effort to satisfy the needs and desires of buyers, in order to obtain sales that generate profit (Marwan Asri Asri (1991) ). Sales are a source of life for a company because sales can be obtained from profits and measure the extent of consumer attraction to the results of the product. This final production activity becomes the company's leading activity in producing something because it will increase the acceptance and even the value of the company. Changes in the level of sales between before and after ACFTA in this study are expected to represent changes in financial performance of the concerned SMEs in the implementation of ACFTA in Indonesia.

\section{METHODS AND MATERIALS}

This study uses mix methods, namely the step of research by combining two forms of approaches in research, both qualitative and quantitative (Creswell Creswell (2010) ). According to (Sugiyono Sugiyono (2017)) mix methods are research methods by combining two research methods at once, qualitative and quantitative in a research activity, so that more comprehensive, valid, and objective data will be obtained. This study uses a squared mix method, especially sequential eskplanatoris strategy. The first stage is to find quantitative data in advance at the Central Bureau of Statistics (BPS), the Office of Cooperatives and the Industry and Trade Office of the Sidoarjo Regency, then the second step is to find various information, news analysis, concepts of thoughts of experts published in the book, scientific papers, articles, internet, print media, and journals relating to the issues to be discussed. The location of the study was conducted in Sidoarjo regency, the selection of research sites was based on data obtained from the BPS (Central Bureau of Statistics), the Office of Cooperatives and the Department of Industry and Trade of Sidoarjo Regency, regarding the SMEs in Sidoarjo Regency.

The population taken in this study were all UKM in Sidoarjo. This study uses the financial statements of SMEs in Sidoarjo to find out the financial performance seen from the sale of UKM in Sidoarjo. The sample selection is done by using purposive sampling method with the aim to get a representative sample according to the specified criteria.

Teknik dalam mix method dengan strategi metode campuran bertahap (squential mixed methods) terutama strategi eks- 
TABLE 1 | Number SMEs and LSEs inKabupaten Sidoarjo

\begin{tabular}{lll}
\hline Districts & UKM & Distribution (\%) \\
Tarik & 5.510 & 2,68 \\
Prambon & 8.721 & 4,25 \\
Krembung & 5.763 & 2,81 \\
Porong & 6.711 & 3,30 \\
Jabon & 4.787 & 2,33 \\
Tanggulangin & 7.556 & 3,72 \\
Candi & 14.437 & 7,09 \\
Tulangan & 8.690 & 4,25 \\
Wonoayu & 6.875 & 3,39 \\
Sukodono & 8.510 & 4,17 \\
Sidoarjo & 20.408 & 10,20 \\
Buduran & 8.905 & 4,47 \\
Sedati & 9.299 & 4,69 \\
Waru & 32.058 & 15,92 \\
Gedangan & 13.303 & 6,71 \\
Taman & 20.860 & 10,38 \\
Krian & 13.536 & 6,71 \\
Balongbendo & 5.990 & 2,94 \\
Sidoarjo & 201.919 & 100,00 \\
\hline & &
\end{tabular}

TABLE 2 | Sample Selection Result

\begin{tabular}{lll}
\hline No & Sample Criteria & Number \\
1 & Number of SMEs in Sidoarjo & 201,919 \\
2 & Active SMEs in Tanggulangin (Commodities like bag, luggage, shoes, leather jacket) & 252 \\
3 & SMEs that have completed financial reports & 63 \\
4 & SMEs with complete data of variables being used in the research & 48 \\
Total (2016 and 2017) & 48 \\
\hline
\end{tabular}

planatoris sekuensial merupakan strategi bagi peneliti untuk menggabungkan data yang ditemukan dari satu metode dengan metode lainnya. Pertama akan mencari data kuantitatif yang di ji degan Paired Samples T test kemudian data kualitatif dengan melakukan penelitian kepustakaan (Library Research). Techniques in mix methods with stepwise mixed method strategies, especially sequential explanatory strategies, are strategies for researchers to combine data found from one method to another. First, quantitative data is obtained with Paired Samples T test, and second, qualitative data is obtained by library research.

\section{RESULTS AND DISCUSSION}

This Descriptive Statistics gives a description of the value of the dependent variable and the independent variable, which is the average value of the standard deviation, which can be seen in the following table.

Source:Analyzed by the researcher, 2018

Table 3 shows the measurement of $\mathrm{N}$ variables as many as 48 in the 2009 and 2011 periods regarding descriptive statistics using SPSS 18. It can be explained that the results of variable calculations before ACFTA can be seen in table 4.1. This shows the measurement of variables from $\mathrm{N}$ as many as 48 in the period 2009 and 2010 has a minimum value of 50, maximum 100, mean (average value) 85.10, and Standard Devia- tion (standard deviation) of this variable is 13.442. Meanwhile, the result of variable calculation after ACFTA shows $48 \mathrm{~N}$ variable measurements, has a minimum value of 75 , maximum 100 , mean (average value) 90.73, and the Standard Deviation (standard deviation) of this variable is 7.219.

\section{a. Data Quality Test \\ 1. Normality Test}

Normality Test aims to test whether in the regression model, the independent variable and the dependent variable both have a normal distribution. Testing can be done in various ways, one of them with Kolmogorov-Smirnov with the following criteria.

- If the significant variable value is more than $5 \%$ (sig > 5\%) the data is considered normal.

- If the significant variable value is less than $5 \%(>5 \%) \%)$ the data is not distributed as normal.

Source: Output SPSS, data is processed in 2018

Based on the results of the normality test data in table 4.2, the influence of ACFTA on financial performance is seen from the level of sales before and after ACFTA with a probability level $>0.05$ which data is normally distributed. The significance value before ACFTA is $0.149>0.05$ and the significance value after ACFTA is $0.133>0.05$.

b. Hypothesis Test

1. Hypotheses Test

Testing is done by testing parametric statistics by using 
TABLE 3 | Descriptive statistics

\begin{tabular}{llllll}
\hline Descriptive Statistics & & & & \\
& & Minimum & Maximum & Mean & Std. Deviation \\
presale & 48 & 50 & 100 & 85,10 & 13,428 \\
Post-sale & 48 & 75 & 100 & 90,73 & 7,219 \\
\hline Valid N (listwise) & 48 & \multicolumn{1}{l}{} \\
\hline
\end{tabular}

TABLE 4 | Normality Test Result (One-Sample Kolmogorov-Smornov Test)

\begin{tabular}{|c|c|c|c|}
\hline \multicolumn{4}{|c|}{ One-Sample Kolmogorov-Smirnov Test } \\
\hline \multirow{5}{*}{$\begin{array}{l}\text { Normal Parametersa,b } \\
\text { Std. Deviation }\end{array}$} & & Presale & Post-sale \\
\hline & & 48 & 48 \\
\hline & Mean & 85,10 & 90,73 \\
\hline & 13,428 & 7,219 & \\
\hline & Absolute &, 164 &, 168 \\
\hline Plositivextreme Differences & ,134 & ,124 & \\
\hline Negative &,- 164 &,- 168 & \\
\hline \multicolumn{2}{|l|}{ Kolmogorov-Smirnov Z } & 1,139 & 1,165 \\
\hline \multicolumn{2}{|l|}{ Asymp. Sig. (2-tailed) } & ,149 &, 133 \\
\hline \multicolumn{4}{|c|}{ a. Test distribution is Normal. } \\
\hline \multicolumn{4}{|l|}{ b. Calculated from data. } \\
\hline
\end{tabular}

Paired Samples T-test. This test is used to find out if there are differences in the average of the two related samples, with the same fixed sample, only different cases before and after ACFTA. This test uses SPSS version 18.0 program.

This hypothesis tests the financial performance seen from the level of sales. The use of the Paired Samples T test is intended to test whether there is a difference in the level of sales that leads to an increase or decrease after the ACFTA. Paired Samples T-test test results can be seen in table 5 .

Source: processed by the reearcher, 2018.

Based on the results of research that refers to data processing in accordance with the title of the research, problems and research hypotheses, there are several things that need to be explained as follows:

The average UKM in Sidoarjo Regency has various sources of capital, not only relying on its own capital but sources of funds from outside parties. The average UKM feels able to compete in the face of invasion of Chinese products. According to Herawati Herawati (2010), sales that experienced a reasonable decline can be accepted because of the competitiveness of local products with Chinese products which are known for their low prices and competative quality. Significant increases in sales that need to be reviewed and maintained to be able to maintain local products from Chinese products.

In mid-2016, the number of SMEs in Indonesia reached 57.9 million. According to Deputy for Production and Marketing of the Ministry of Cooperatives and Small and Medium Enterprises, I Wayan Dipta, this number has the potential to go international. The government itself is now fully encouraging the SMEs to go international. One way is to teach them to use the internet which is one way to facilitate marketing to the international market. Sidoarjo Regency Government encourages small and medium enterprises (SMEs) to market their products abroad. Sidoarjo Regent Saiful Ilah said that many SME products from Sidoarjo were exported. He added, the dis- trict government tried to encourage the development of SMEs through various ways. In addition to coaching, the district government also facilitates financing schemes through revolving funds. "Loans without collateral without collateral, low interest is only 6 percent. He gave an example, sandals commonly purchased by Muslims during Umrah or Hajj in Saudi Arabia are products from Waru, Sidoarjo. In addition, shoes, sandals and leather bags from Tanggulangin are also exported to a number of countries.

Based on the analysis of the data above, the increase in sales could have occurred due to the export business that was started by SMEs in Sidoarjo, especially commodities such as Bags, Suitcases/ luggare, Shoes, Leather Jackets so that it rose because it was offset by exports in addition to receiving Chinese products into the market. Besides that the role of the Government in Sidoarjo regency was also successful in fostering cooperatives and MSMEs so that it made Sidoarjo Regency designated as the City of Indonesian SMEs.

\section{CONCLUSION}

Based on the results of testing hypotheses about different levels of sales before and after ACFTA, it can be concluded that the implementation of the ASEAN China Free Trade Agreement (ACFTA) in Indonesia in 2010 have a significant influence on the level of sales of SMEs in Sidoarjo. So when it is viewed from the level of sales alone, the financial performance before and after the entry into force of ACFTA experienced a significant difference. However, the increase in sales rates is not strong enough to prove the difference in financial performance in SMEs after the enactment of ACFTA. There are still other indicators that are evaluating financial performance. 
TABLE 5 | Paired Samples T test Result

\begin{tabular}{|c|c|c|c|c|c|c|c|c|c|}
\hline \multicolumn{10}{|c|}{ Paired Samples Test } \\
\hline & & \multicolumn{8}{|c|}{ Paired Differences } \\
\hline & & \multirow[t]{2}{*}{ Mean } & \multirow[t]{2}{*}{ Std. Deviation } & \multirow[t]{2}{*}{ Std. Error Mean } & \multicolumn{2}{|c|}{$\begin{array}{l}95 \% \text { Confidence } \\
\text { Interval of the } \\
\text { Difference }\end{array}$} & T & df & Sig. (2-tailed) \\
\hline & & & & & Lower & Upper & & & \\
\hline Pair 1 & Penjalan_sebelum - Penjualan_sesudah & $-5,625$ & 16,099 & 2,324 & $-10,300$ &,- 950 & $-2,421$ & 47 & 019 \\
\hline
\end{tabular}

\section{ACKNOWLEDGEMENTS}

Acknowledgments to fellow lecturers who have helped and supported the completion of this article.

\section{REFERENCES}

A, H. E. (1996). Financial Management (Jakarta: Erlangga)

Asri, M. (1991). Marketing (Cetakan II) (Yogyakarta: UPP AMP YKPN)

Creswell, J. W. (2010). Research Design : Pendekatan Kualitatif, Kuantitatif dan Mixed (Yogyakarta: Pustaka Pelajar)

Efnita, Y. (2012). Pengaruh ASEAN China Free Trade Area (ACFTA) Terhadap Pertumbuhan Ekonomi di Indonesia. Jurnal Ekonomi, Manajemen Dan Akuntansi I 19

Herawati, V. (2010). No Title. Pengaruh Asean China Free Trade Agreement Terhadap KInerja Keuangan Yang Dilihat Dari Penjualan UKM Tekstil Di Pekalongan

Mulyadi (1997). Akuntansi Manajemen: Konsep, Manfaat dan Rekayasa

Statistik, B. P. (2017). Kabupaten Sidoarjo Dalam Angka (Sidoarjo: Badan Pusat Statistik)
Sugiyono (2017). Metodologi Penelitian Kuantitatif, Kualitatif, dan R\&D (Bandung: Alfabeta)

Yola, S. V. (2017). Pengaruh Asean China Free Trade Agreement (ACFTA) terhadap ekspor komoditi kelapa sawit dan karet alam Indonesia

Conflict of Interest Statement: The authors declare that the research was conducted in the absence of any commercial or financial relationships that could be construed as a potential conflict of interest.

Copyright $(2019$ Setiyono, Andriyani and Putra. This is an open-access article distributed under the terms of the Creative Commons Attribution License (CC BY). The use, distribution or reproduction in other forums is permitted, provided the original author(s) and the copyright owner(s) are credited and that the original publication in this journal is cited, in accordance with accepted academic practice. No use, distribution or reproduction is permitted which does not comply with these terms. 